\title{
スポーツ雑誌に拉ける栄養関連記事の内容
}

\author{
依田育美，森早苗，大村加奈，金子佳代子 \\ (横浜国立大学教育人間科学部)
}

\section{Analysis of Nutrition Articles in Magazines for Athletes}

Ikumi Yoda, Sanae Mori, Kana Omura and Kayoko Kaneko

Faculity of Education and Human Sciences, Yokohama National University, 79-2,

Tokiwadai, Hodogaya-ku, Yokohama, 240-8501

于240-8501 横浜市保土ケ谷区常盤台79-2

\begin{abstract}
Nutrition information from in Six journals published from 1992 to 1996 about athletes was examined.

Articles about food and nutrition that appeared in the journals were written by dietitians, medical doctors, professors, coaches and so on. The contents of the articles were classified into twenty- one groups which contained information about nutritious food, nutrient balance, conditioning, fatigue reduction its. Most of the descriptions about nutrients and their functions were as popular as those described in textbooks for high school students, and some were specific ally related to exercise physiology. In some articles the authors described nutrirent allowances but no information about their sources.
\end{abstract}

A few authors mentioned supplements of energy, protein, vitamin, calcium and iron supplementation.

\section{1. 緒言}

スポーツ栄養学への関心の高まりとともに, 各種競技 のスポーツマンを対象として雑誌に栄養・食生活に関す る記事の掲載が増加している. 大学運動部所属学生を対 象とした調査 ${ }^{1)} に$ に打いても栄養・食生活に関する知識の 情報源としてスポーツ雑誌をあげる者が多くみられ, 高 校生から成人のスポーツマンにこれら雑誌の記事が広く 情報を提供していると考えられる.

スポーツマンにとって栄養・食生活は, 健康を維持し, トレーニングの成果を十分に発揮させて競技力を向上さ せるために重要な要素であるが，それは特殊な食物や栄 養素によるものではなく, すべての人に共通する基本的 な栄養学の知見を基盤とするものである. 栄養. 食生活
に関する基礎的な知識は，学校教育において主に家庭科 で学習することになっているが，そこで学習する内容と スポーツ雑誌から得られる情報との間にギャップがある 場合には，情報が生活に生かされないばかりかかえって 混乱が生ずることにもなりかねない.

そこで本研究では，スポーツ雑誌に捺ける栄養・食生 活に関する記事の実態を調査し, 取り上げられているこ とがらや記述内容を検討することを目的とし，特に栄養 素とその働きについては高等学校家庭科に打訬る学習内 容との関連性について比較検討を行った.

\section{2. 研究方法}

雑誌の選定にあたっては，わが国において競技人口の 多い種目执よび競技特性が偏らないよらにすることを考 
慮してサッカー，野球，陸上競技，柔道を，またトレー ニング等に科学的な知見を取り入れることに積極的なア メリカンフットボールを取り上げ，さらに読者層の広い 雑誌として「ランナーズ」を加えた. 表 1 に示したスポー ツ雑誌 6 誌に, 1992年 8 月〜 1996年 8 月の 5 年間に掲載 されたスポーツ栄養関連記事を対象として, 以下の項目 について分析，検討を行った.

表 1 対象としたスポーツ雑誌

\begin{tabular}{|c|c|c|}
\hline 競技種目 & 雑 誌 名 & 出 版 社 \\
\hline サッカー & サッカークリニック & ベースボールマガジン社 \\
\hline 野球 & ベースボールクリニック & ベースボールマガジン社 \\
\hline 陸上競技 & $\begin{array}{l}\text { 陸上競技マガジン } \\
\text { ランナーズ }\end{array}$ & $\begin{array}{l}\text { ベースボールマガジン社 } \\
\text { ランナーズ社 }\end{array}$ \\
\hline 柔道 & 近代柔道 & ベースボールマガジン社 \\
\hline フメリカンフットポール & フットボールマガジン & ベースボールマガジン社 \\
\hline
\end{tabular}

（1）栄責関連記事掲載数

(2) 執筆者

執筆者の肩書きから, 栄養士, 医師, 大学教員, 調 理師等（調理師及びフードューディネーター），コー チ，その他に分類した。

(3) 記事内容

栄養関連記事の内容を表すキーワードを,タイトル， 見出し, 文章中から抽出し, 分類整理した.

(4) 栄養素, 食品に関与る記述内容

栄養関連記事の本文, 図表中に記述された栄養素名, その働さ, 必要量, 食品名拈よび摂取すべさめやす量, 栄養補助食品を抽出し, その有無と内容をまとめた.

また，栄養素の種類と働きについて，現行（平成 5 年発行) の高等学校教科書「家庭一般」7冊に拉ける 記述内容を調査し, 上記スポーツ雑誌に扣ける記述内 容との比較を行った.

\section{3. 結果および考察}

\section{（1）栄養関連記事掲載数}

6 誌のらち「近代柔道」については 5 年間通して栄養 関連記事はみられなかった。これ以外の 5 誌についての 掲載状況は表 2 のよ拈りである.

5 年間の総合計ページ数は434ページであり, 雑誌 1 冊あたりの平均ページ数は「ランナーズ」4.1,「陸上競 技マガシン」2.1,「サッカークリニック」1.6,「ベース ボールクリニック」 1.3 ,「フットボールマガジン」 0.9 ページであった．雑誌別でみると「ランナーズ」が最も 多かった（199ページ）が，このらち77ページは読者か らの情報記事であり，これを除いた122ページ（総合計
表 2 雑誌別栄養関連記事の掲載ページ数

\begin{tabular}{c|r|r|r|r|r}
\hline & $\begin{array}{r}\text { サッカー } \\
\text { クニック }\end{array}$ & $\begin{array}{r}\text { クリースホール } \\
\text { クリク }\end{array}$ & $\begin{array}{l}\text { 陸上競技 } \\
\text { マカジン }\end{array}$ & $\begin{array}{r}\text { フッホホール } \\
\text { マガジン }\end{array}$ & ランナーズ \\
\hline 1992年 & $0(0.0)$ & $8(1.9)$ & $8(0.6)$ & $5(0.8)$ & $15(1.5)$ \\
1993年 & $0(0.0)$ & $11(1.1)$ & $29(0.8)$ & $11(0.7)$ & $46(2.2)$ \\
1994年 & $4(1.8)$ & $9(0.9)$ & $24(0.7)$ & $11(0.8)$ & $54(2.3)$ \\
1995年 & $24(1.8)$ & $19(1.8)$ & $24(0.7)$ & $10(0.7)$ & $41(1.6)$ \\
1996年 & $8(0.9)$ & $8(1.2)$ & $14(0.7)$ & $8(0.8)$ & $43(2.7)$ \\
\hline 合計 & $36(1.4)$ & $55(1.3)$ & $99(0.7)$ & $45(0.7)$ & $199(2.1)$ \\
\hline 一冊あたり & 1.6 & 1.3 & 2.1 & 0.9 & 4.1 \\
\hline
\end{tabular}

（）内は全ページ数に対する割合（\%)

数357ページ）を記事内容抢よび栄養素，食品に関する 記事内容の検討対象とした.

\section{(2) 執筆者}

各雑誌の栄養記事の執筆者について表 3 にまとめた.

表 3 栄養関連記事の執筆者別件数

\begin{tabular}{l|r}
\hline \multicolumn{1}{c|}{ 執 筆 者 } & 記事件数 $(\%)$ \\
\hline 栄養士 & $140(43.5)$ \\
医師 & $104(32.3)$ \\
大学教員 & $28(8.7)$ \\
調理師等 & $24(7.5)$ \\
コーチ & $23(7.1)$ \\
その他 & $3(0.9)$ \\
\hline \multicolumn{1}{c|}{ 合計 } & $322(100)$ \\
\hline
\end{tabular}

全雑誌でみると栄養士 (140件，43.5\%)，医師（104 件, 32.3\%) によるものが多く, 次いで大学教員, 調理 師等, コーチによるものであった. 雑誌別にみると、「サ ッカークリニック」,「フットボールマガジン」では医師 のみ,「陸上競技マガジン」では栄養士のみ,「ベースボー ルクリニック」,「ランナーズ」では栄養士, 医師, 大学 教員, 調理師等, コーチと多様であった。

\section{(3) 記事内容}

記事内容を表すキーワードは，21項目に分類すること ができた（表 4 ）。

「食品紹介」に関する記事が最も多く (60件, 18.6\%), 次いで「栄養バランス」(27件, 8.4\%),「コンディショ ニング」(26件， $8.1 \%)$, 「疲労回復」(24件， $7.5 \%)$ 等 であった。

雑誌による違いをみると,「サッカークリニック」,「フ ットボールマガジン」では「からだづくり」や「コンデ ィショニング」に関する記事が多くみられ,「陸上競技 マガジン」ではその他に「貧血防止」が，本た「ランナー ズ」でも「貧血防止」に関する記事が多いなど，各競技 の特性に関連すると思われる傾向がみられた。 また，記 
表 4 記事内容の雑誌別件数

\begin{tabular}{|c|c|c|c|c|c|c|}
\hline 記 事 内 容 & $\begin{array}{l}\text { サッカー } \\
\text { クリニック }\end{array}$ & $\begin{array}{c}\text { ベースボール } \\
\text { クリニック }\end{array}$ & $\begin{array}{l}\text { 陸上競技 } \\
\text { マガジン }\end{array}$ & $\begin{array}{c}\text { フットボール } \\
\text { マガジン }\end{array}$ & ランナーズ & 計 \\
\hline 食品紹介 & $0(0.0)$ & $4(10.3)$ & $14(18.7)$ & $10(15.9)$ & $32(27.8)$ & $60(18.6)$ \\
\hline 栄養バランス & $0(0.0)$ & $3(7.7)$ & $13(17.3)$ & $0(0.0)$ & $11(9.6)$ & $27(8.4)$ \\
\hline コンディショニング & $5(16.7)$ & $1(2.6)$ & $8(10.7)$ & $7(11.1)$ & $5(4.3)$ & $26(8.1)$ \\
\hline 疲労回復 & $3(10.0)$ & $3(7.7)$ & $7(9.3)$ & $1(1.6)$ & $10(8.7)$ & $24(7.5)$ \\
\hline 貧血防止 & $0(0.0)$ & $0(0.0)$ & $6(8.0)$ & $2(3.2)$ & $14(12.2)$ & $22(6.8)$ \\
\hline からだづくり & $6(20.0)$ & $1(2.6)$ & $7(9.3)$ & $6(9.5)$ & $0(0.0)$ & $20(6.2)$ \\
\hline 水分補給 & $2(6.7)$ & $6(15.4)$ & $2(2.7)$ & $5(7.9)$ & $6(5.2)$ & $21(6.5)$ \\
\hline 摂取タイミング & $0(0.0)$ & $6(15.4)$ & $0(0.0)$ & $5(7.9)$ & $9(7.8)$ & $20(6.2)$ \\
\hline 栄養素説明 & $8(26.7)$ & $0(0.0)$ & $0(0.0)$ & $10(15.9)$ & $1(0.9)$ & $19(5.9)$ \\
\hline 持久カアップ & $2(6.7)$ & $2(5.1)$ & $4(5.3)$ & $3(4.8)$ & $7(6.1)$ & $18(5.6)$ \\
\hline カーボーローディング & $2(6.7)$ & $0(0.0)$ & $1(1.3)$ & $1(1.6)$ & $7(6.1)$ & $11(3.4)$ \\
\hline 減量 & $0(0.0)$ & $1(2.6)$ & $3(4.3)$ & $0(0.0)$ & $7(6.1)$ & $11(3.4)$ \\
\hline ウエイトコントロール & $0(0.0)$ & $0(0.0)$ & $0(0.0)$ & $9(14.3)$ & $0(0.0)$ & $9(2.5)$ \\
\hline 試合当日の食事 & $0(0.0)$ & $3(7.7)$ & $1(1.3)$ & $1(1.6)$ & $4(3.5)$ & $9(2.5)$ \\
\hline 食事調査 & $0(0.0)$ & $0(0.0)$ & $7(9.3)$ & $0(0.0)$ & $0(0.0)$ & $7(2.2)$ \\
\hline 朝食について & $0(0.0)$ & $2(5.1)$ & $2(2.7)$ & $1(1.6)$ & $0(0.0)$ & $5(1.6)$ \\
\hline 試合前の食事 & $0(0.0)$ & $2(5.1)$ & $0(0.0)$ & $1(1.6)$ & $1(0.9)$ & $4(1.2)$ \\
\hline 食生活改善 & $0(0.0)$ & $3(7.7)$ & $0(0.0)$ & $1(1.6)$ & $0(0.0)$ & $4(1.2)$ \\
\hline トレーニング期の食事 & $2(6.7)$ & $0(0.0)$ & $0(0.0)$ & $0(0.0)$ & $0(0.0)$ & $2(0.6)$ \\
\hline 栄養教育 & $0(0.0)$ & $2(5.1)$ & $0(0.0)$ & $0(0.0)$ & $0(0.0)$ & $2(0.6)$ \\
\hline 試合後の食事 & $0(0.0)$ & $0(0.0)$ & $0(0.0)$ & $0(0.0)$ & $1(0.9)$ & $1(0.3)$ \\
\hline 計 & $30(100)$ & $39(100)$ & $75(100)$ & $63(100)$ & $115(100)$ & $322(100)$ \\
\hline
\end{tabular}

（）内の数值は\%

事内容を掲載月で比較してみると，「水分補給」に関す る記事が 7 月から 9 月にかけて，また「からだづくり」 関する記事が 1 月から 4 月にかけて多く揭載されてお り，季節による特徵がみられた．夏期には熱中症予防や 発汗による脱水症を防ぐために「水分補給」が重要と考
えられ，1〜3月は次のシーズンに向けて「からだづく り」が重視される時期であることに対応したものと考党 られる.

これら記事の内容は読者に関心の高いもの，編集者あ るいは執筆者がスポーッマンに必要と考えているものと

表 5 栄養素，食品に関する記載内容の分類（執筆者別）

\begin{tabular}{|c|c|c|c|c|c|c|c|}
\hline \multirow{2}{*}{ 記載内容の分類 } & \multicolumn{6}{|c|}{ 執 筆 者 } & \multirow[t]{2}{*}{ 計 } \\
\hline & 栄養士 & 医 師 & 大学教員 & 調理師等 & コーチ & その他 & \\
\hline (1)食品のみをあげている記事 & $34(42.5)$ & $15(18.8)$ & $9(11.3)$ & $18(22.5)$ & $4(5.0)$ & $0(0.0)$ & $80(100)$ \\
\hline 食品のみ & $29(63.0)$ & $15(32.6)$ & $0(0.0)$ & $1(2.2)$ & $1(2.2)$ & $0(0.0)$ & $46(100)$ \\
\hline 食品十めやす量 & $5(14.7)$ & $0(0.0)$ & $9(26.5)$ & $17(50.0)$ & $3(8.8)$ & $0(0.0)$ & $34(100)$ \\
\hline (2)栄養素のみをあげている記事 & $20(27.8)$ & $40(55.6)$ & $7(9.7)$ & $0(0.0)$ & $4(5.6)$ & $1(1.4)$ & $72(100)$ \\
\hline 栄養素のみ & $1(33.3)$ & $2(66.7)$ & $0(0.0)$ & $0(0.0)$ & $0(0.0)$ & $0(0.0)$ & $3(100)$ \\
\hline 栄養素十働き & $16(32.0)$ & $23(46.0)$ & $7(14.0)$ & $0(0.0)$ & $3(6.0)$ & $1(2.0)$ & $50(100)$ \\
\hline 栄養素＋働き十必要量 & $3(15.8)$ & $15(78.9)$ & $0(0.0)$ & $0(0.0)$ & $1(5.3)$ & $0(0.0)$ & $19(100)$ \\
\hline (3)食品と栄養素をあげている記事 & $86(50.6)$ & $49(28.8)$ & $12(7.1)$ & $6(3.5)$ & $15(8.8)$ & $2(1.2)$ & $170(100)$ \\
\hline 食品十栄養素 & $39(60.9)$ & $13(20.3)$ & $2(3.1)$ & $2(3.1)$ & $6(9.4)$ & $2(3.1)$ & $64(100)$ \\
\hline 食品＋栄養素＋働き & $44(49.4)$ & $24(27.0)$ & $10(11.2)$ & $3(3.4)$ & $8(9.0)$ & $0(0.0)$ & $89(100)$ \\
\hline 食品+栄養素+必要量 & $1(25.0)$ & $2(50.0)$ & $0(0.0)$ & $0(0.0)$ & $1(25.0)$ & $0(0.0)$ & $4(100)$ \\
\hline 食品十栄養素十働き十必要量 & $2(15.4)$ & $10(76.9)$ & $0(0.0)$ & $1(7.7)$ & $0(0.0)$ & $0(0.0)$ & $13(100)$ \\
\hline
\end{tabular}


思われるが，具体的な「食品紹介」や「栄養バランス」 などの基礎的なことがらが数多く取り上げられているこ とは，こうした知識の普及が不十分であることを示唆し ていると思われる。

\section{（4）栄養素，食品に関する記載内容}

\section{1）栄養素, 食品に関する記載}

栄養素, 食品に関する記載内容を (1)食品のみ取り上 げているもの（2)栄養素のみ取り上げているもの (3)食 品とそれに含まれる栄養素をあげているものの 3 つのパ ターンに分類し，執筆者分類別にまとめた結果を表 5 に 示した。 (1) 80 件 (24.8\%), (2)72件 (22.4\%), (3170件 (52.8\%) と，(3)食品とそれに含まれている栄養素を併 せてとりあげている記事が最も多くみられた。執筆者別 でみると，医師，栄養士，大学教員，コーチでは(3)が多

く, 調理師等では(1)が多いといら特徵がみられた.

これら 3 分類した記事各々について, さらに詳しくみ
ると, (1) 食品のみを取り上けている記事80件中34件 (42. 5\%）に，摂取すべきめやす量の記載がみられ，筆者別 でみると調理師等による記事 (17件)，大学教員による 記事（9件）が多かった。

(2) 栄養素のみを取り上げている記事では，栄養素と その働きについての記述のある記事が多く（50件，69.4 \%) みられ，また必要量についても記載されたものが19 件 $(26.4 \%)$ みられた。

(3) 食品と栄養素を取り上げている記事では，食品と それに含まれる栄養素 $(64$ 件，37.6\%)，食品と栄養素 及びその㗢き $(89$ 件， $52.4 \%)$ について記載されたもの が多く, 栄養素の必要量を記載したものは少なかった。

\section{2）栄養素とその働きについての記載内容}

栄養素とその働きに関する記載内容について，高等学 校の家庭科教科書に記述されている内容との比較もあわ せて表 6 にまとめた。

表 6 栄養素とその働きに関する記載内容

\begin{tabular}{|c|c|c|c|c|c|c|c|c|}
\hline \multirow{2}{*}{ 栄養素 } & \multirow{2}{*}{ 働 } & \multicolumn{7}{|c|}{ 執 筆 者 別 件 数 } \\
\hline & & 栄養士 & 医師 & 大学教員 & 調理師等 & コーチ & その他 & 計 \\
\hline \multirow[t]{8}{*}{ 炭水化物 } & *エネルギー源 & 9 & 4 & 2 & 0 & 4 & 0 & 19 \\
\hline & *グリコーゲン貯蔵 & 0 & 2 & 3 & 0 & 0 & 0 & 5 \\
\hline & 脳を活性化 & 5 & 1 & 0 & 0 & 0 & 0 & 6 \\
\hline & 血糖值をあげる & 1 & 1 & 0 & 0 & 0 & 0 & 2 \\
\hline & 血糖値維持 & 0 & 0 & 0 & 0 & 2 & 0 & 2 \\
\hline & 疲労回復 & 0 & 1 & 1 & 0 & 0 & 0 & 2 \\
\hline & 体力の低下防止 & 0 & 1 & 0 & 0 & 0 & 0 & 1 \\
\hline & エネルギーの再合成 & 0 & 1 & 0 & 0 & 0 & 0 & 1 \\
\hline 果糖 & 脂肪をエネルギーに変える & 0 & 0 & 1 & 0 & 0 & 0 & 1 \\
\hline \multirow[t]{2}{*}{ 脂質 } & *エネルギー源 & 0 & 3 & 1 & 0 & 0 & 0 & 4 \\
\hline & 夏バテ防止 & 0 & 0 & 1 & 0 & 0 & 0 & 1 \\
\hline \multirow[t]{7}{*}{ たんばく質 } & 疲労回復 & 3 & 0 & 1 & 0 & 1 & 0 & 5 \\
\hline & *へモグロビン合成 & 1 & 3 & 1 & 0 & 0 & 0 & 5 \\
\hline & *筋肉づくりの材料 & 3 & 4 & 3 & 1 & 1 & 0 & 12 \\
\hline & 血中リンパの増加 & 0 & 1 & 0 & 0 & 0 & 0 & 1 \\
\hline & 腱, 鞀帯合成 & 0 & 1 & 0 & 0 & 0 & 0 & 1 \\
\hline & *エネルギー源 & 0 & 1 & 0 & 0 & 0 & 0 & 1 \\
\hline & *酵素となる & 0 & 1 & 0 & 0 & 0 & 0 & 1 \\
\hline \multirow[t]{5}{*}{ ビタミン $\mathrm{A}$} & *視覚に関係 & 1 & 2 & 0 & 0 & 0 & 0 & 3 \\
\hline & *抗癌作用 & 1 & 2 & 0 & 0 & 0 & 0 & 3 \\
\hline & 免疫力に関係 & 1 & 0 & 0 & 0 & 0 & 0 & 1 \\
\hline & *粘膜の機能維持 & 0 & 2 & 0 & 0 & 0 & 0 & 2 \\
\hline & 細胞膜防御 & 1 & 1 & 0 & 0 & 0 & 0 & 2 \\
\hline \multirow[t]{5}{*}{ ビタミン B 群 } & *炭水化物代謝に関与 & 2 & 2 & 1 & 0 & 1 & 0 & 6 \\
\hline & 緊張緩和 & 0 & 1 & 0 & 0 & 0 & 0 & 1 \\
\hline & 血圧抑制 & 0 & 1 & 0 & 0 & 0 & 0 & 1 \\
\hline & 乳酸分解 & 1 & 0 & 0 & 0 & 0 & 0 & 1 \\
\hline & 疲労回復に関与 & 3 & 0 & 0 & 0 & 1 & 0 & 4 \\
\hline \multirow[t]{4}{*}{ ビタミン $\mathrm{B}_{1}$} & *炭水化物の代謝促進 & 4 & 2 & 0 & 0 & 0 & 0 & 6 \\
\hline & 脳の発育 & 0 & 1 & 0 & 0 & 0 & 0 & 1 \\
\hline & 疲労回復 & 2 & 1 & 0 & 0 & 0 & 0 & 3 \\
\hline & ＊神経機能に関与 & 0 & 1 & 0 & \begin{tabular}{l|l}
0 \\
\end{tabular} & 0 & 0 & 1 \\
\hline
\end{tabular}


日本食生活学会誌 Vol.9 No.3（1998）

\begin{tabular}{|c|c|c|c|c|c|c|c|c|}
\hline \multirow[t]{3}{*}{ ビタミンン $\mathrm{B}_{2}$} & 疲労回復に関与 & 0 & 1 & 1 & 0 & 0 & 0 & 2 \\
\hline & *成長ホルモン合成に関与 & 0 & 1 & 0 & 0 & 0 & 0 & 1 \\
\hline & *炭水化物の代謝促進 & 1 & 0 & 0 & 0 & 0 & 0 & 1 \\
\hline ビタミン $\mathrm{B}_{6}$ & *アミノ酸代謝の補酵素 & 0 & 1 & 0 & 0 & 0 & 0 & 1 \\
\hline ナイアシン & トリプトファン代謝に関与 & 0 & 1 & 0 & 0 & 0 & 0 & 1 \\
\hline \multirow[t]{2}{*}{ ペントデン酸 } & アセチル $\mathrm{CoA}$ の構成成分 & 0 & 1 & 0 & 0 & 0 & 0 & 1 \\
\hline & 神経や副腎皮質の機能維持 & 0 & 1 & 0 & 0 & 0 & 0 & 1 \\
\hline \multirow[t]{2}{*}{ ビタミン $\mathrm{B}_{12}$} & D N Aの再合成, 修復に関与 & 0 & 1 & 0 & 0 & 0 & 0 & 1 \\
\hline & 細胞の分裂，修復に関与 & 0 & 1 & 0 & 0 & 0 & 0 & 1 \\
\hline イノシトール & 脂肪を乳化, コレステロールの畜積防止 & 0 & 1 & 0 & 0 & 0 & 0 & 1 \\
\hline コリン & 脂肪を乳化, コレステロールの畜積防止 & 0 & 1 & 0 & 0 & 0 & 0 & 1 \\
\hline \multirow[t]{14}{*}{ ビタミンC } & 米抗ストレス作用 & 4 & 4 & 0 & 0 & 1 & 0 & 9 \\
\hline & *免疫作用 & 1 & 2 & 0 & 0 & 0 & 0 & 3 \\
\hline & 疲労回復 & 1 & 0 & 0 & 1 & 1 & 0 & 3 \\
\hline & *鉄の吸収促進 & 1 & 1 & 1 & 0 & 1 & 0 & 4 \\
\hline & *血管壁を厚くする & 0 & 1 & 0 & 0 & 0 & 0 & 1 \\
\hline & 腱, 靫帯強化 & 1 & 4 & 0 & 0 & 0 & 0 & 5 \\
\hline & インシュリンの分泌促進 & 0 & 1 & 0 & 0 & 0 & 0 & 1 \\
\hline & カルニチン代謝に関与 & 0 & 1 & 0 & 0 & 0 & 0 & 1 \\
\hline & フリーラジカル除去 & 1 & 1 & 0 & 0 & 0 & 0 & 2 \\
\hline & カテコールアミンの再合成 & 0 & 1 & 0 & 0 & 0 & 0 & 1 \\
\hline & 脂肪酸の分解促進 & 0 & 1 & 0 & 0 & 0 & 0 & 1 \\
\hline & 長鎖脂肪酸の活性化 & 0 & 1 & 0 & 0 & 0 & 0 & 1 \\
\hline & *コンディショニング（風邪，ケガ予防） & 1 & 2 & 0 & 1 & 0 & 0 & 4 \\
\hline & 栄養素の吸収に関与 & 0 & 0 & 0 & 0 & 1 & 0 & 1 \\
\hline ビタミンD & *カルシウムの吸収促進 & 2 & 0 & 0 & 1 & 0 & 0 & 3 \\
\hline \multirow[t]{4}{*}{ ビタミン $\mathrm{E}$} & *過酸化脂質の畜積を防ぐ & 2 & 1 & 0 & 0 & 0 & 1 & 4 \\
\hline & 心肺機能向上 & 0 & 1 & 0 & 0 & 0 & 0 & 1 \\
\hline & 生体機能調整 & 0 & 1 & 0 & 0 & 0 & 0 & 1 \\
\hline & 血行促進 & 1 & 1 & 0 & 0 & 0 & 0 & 2 \\
\hline ミネラル & 筋線維収縮 & 0 & 0 & 0 & 0 & 1 & 0 & 1 \\
\hline 鉄 & *へモグロビン合成 & 8 & 4 & 0 & 0 & 0 & 0 & 12 \\
\hline \multirow[t]{6}{*}{ カルシウム } & *骨の主成分 & 2 & 3 & 0 & 0 & 1 & 0 & 6 \\
\hline & *神経系の安定 & 0 & 3 & 0 & 0 & 0 & 0 & 3 \\
\hline & *血液を中性にする & 0 & 3 & 0 & 0 & 0 & 0 & 3 \\
\hline & *筋繊維の収縮 & 1 & 1 & 0 & 0 & 0 & 0 & 2 \\
\hline & *神経系伝達速度に関与 & 0 & 1 & 0 & 0 & 0 & 0 & 1 \\
\hline & *恒常性維持 & 0 & 1 & 0 & 0 & 0 & 0 & 1 \\
\hline \multirow[t]{3}{*}{ カリウム } & $*$ 笳肉の機能調整 & 1 & 1 & 0 & 0 & 2 & 0 & 4 \\
\hline & 筋痤攣防止 & 0 & 1 & 0 & 0 & 0 & 0 & 1 \\
\hline & 疲労回復 & 0 & 0 & 0 & 0 & 1 & 0 & 1 \\
\hline \multirow[t]{3}{*}{ マグネシウム } & 笳収縮に関与 & 1 & 2 & 0 & 0 & 0 & 0 & 3 \\
\hline & たんぱく質合成促進作用 & 0 & 2 & 0 & 0 & 0 & 0 & 2 \\
\hline & *酵素の活性化 & 0 & 0 & 0 & 0 & 1 & 0 & 1 \\
\hline リン & カルシウムの排泄を促す & 0 & 0 & 0 & 1 & 0 & 0 & 1 \\
\hline
\end{tabular}

*高等学校教科書に記述のみられたことがら

現行の高等学校教科書では, 教科書に上り多少の違い は2られるものの, 炭水化物 (糖質, 食物繊維), 脂質, たんぱく質，無機質（カルシウム，リン，鉄，ナトリウ ム, カリウム, 硫黄, ヨウ素, コバルト, 銅, 亜鉛, フ ッ素, マグネシウム, マンガン, 塩素), ビタミン ( $\mathrm{A}$, $\mathrm{D}, \mathrm{K}, \mathrm{B}_{1}, \mathrm{~B}_{2}, \mathrm{C}$, ナイアシン, $\mathrm{B}_{6}, \mathrm{~B}_{12}$, 葉酸), 水分の各栄養素についてその主な働きが説明されてい る.これ以外にスポーツ雑誌で取り上げられていた栄養
素にはパントテン酸,イノントール，コリンがみられた。 栄養素の働き関する記述には, 教科書で説明されて いる主な働き以外のものもみられた．果糖について脂肪 をエネルギーにかえる，ビタミン B 群について乳酸を分

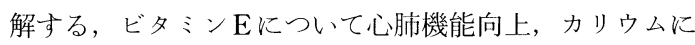
つ、筋痓攣防止, 炭水化物やビタミンと疲労回復や運 動時の代謝とのかかわりに関するものなどがみられ，特 に医師によるものに多い傾向がみられた。 
表 7 栄養素必要量に関する記載件数とその内容

\begin{tabular}{|c|c|c|c|c|}
\hline \multirow{2}{*}{ 栄養素 } & \multicolumn{2}{|r|}{ 執 } & 筆 & \\
\hline & 栄養士 & 医師 & 調理師等 & ユーチ \\
\hline \multirow[t]{2}{*}{ たんぱく質 } & 3 件 & 6 件 & 1 件 & 2 件 \\
\hline & $2.0 \sim 2.5 \mathrm{~g} /$ 体重 $1 \mathrm{~kg}$ & $\begin{array}{l}2.5 \sim 3.0 \mathrm{~g} / \text { 体重 } 1 \mathrm{~kg} \\
40 \sim 50 \mathrm{~g} \\
1 \mathrm{~g} / \text { 体重 } 1 \mathrm{~kg} \\
\text { 試合後 } 20 \mathrm{~g} \\
\text { 就寝前 } 20 \mathrm{~g}\end{array}$ & $2 \mathrm{~g} /$ 体重 $1 \mathrm{~kg}$ & $\begin{array}{l}2.5 \mathrm{~g} / \text { 体重 } 1 \mathrm{~kg} \\
2 \mathrm{~g} / \text { 体重 } 1 \mathrm{~kg}\end{array}$ \\
\hline \multirow[t]{2}{*}{ 脂肪 } & 0 件 & 1 件 & 0 件 & 0 件 \\
\hline & & 1 日 $60 \mathrm{~g}$ & & \\
\hline \multirow[t]{2}{*}{ ビタミンA } & 0 件 & 3 件 & 0 件 & 0 件 \\
\hline & & $\begin{array}{l}10000 \mathrm{IU} \\
5000 \mathrm{IU} \\
10000 \sim 30000 \mathrm{IU}\end{array}$ & & \\
\hline \multirow[t]{2}{*}{ ビタミン B群 } & 1 件 & 0 件 & 0 件 & 0 件 \\
\hline & $1.2 \sim 1.5 \mathrm{mg}$ & & & \\
\hline \multirow[t]{2}{*}{ ビタミン B 1} & 1 件 & 1 件 & 0 件 & 0 件 \\
\hline & 一般の $5 \sim 10$ 倍 & $2 \sim 3 \mathrm{mg}$ & & \\
\hline \multirow[t]{2}{*}{ ビタミンC } & 0 件 & 7 件 & 0 件 & 0 件 \\
\hline & & $\begin{array}{l}3000 \sim 6000 \mathrm{mg} \\
6000 \sim 8000 \mathrm{mg} \\
6000 \mathrm{mg} \sim \\
600 \sim 1200 \mathrm{mg} \\
6000 \mathrm{mg}\end{array}$ & & \\
\hline \multirow[t]{2}{*}{ ビタミン $\mathrm{E}$} & 0 件 & 4 件 & 0 件 & 0 件 \\
\hline & & $\begin{array}{l}400 \mathrm{IU} \sim \\
800 \mathrm{IU} \\
800 \mathrm{IU} \sim \\
800 \sim 1200 \mathrm{IU}\end{array}$ & & \\
\hline \multirow[t]{2}{*}{ カルシウム } & 0 件 & 3 件 & 0 件 & 1 件 \\
\hline & & $\begin{array}{l}1000 \mathrm{mg} \sim \\
800 \sim 1000 \mathrm{mg} \\
1000 \mathrm{mg}\end{array}$ & & -マグネシウムの 2 倍 \\
\hline \multirow[t]{2}{*}{ 鉄 } & 2 件 & 2 件 & 0 件 & 1 件 \\
\hline & $\begin{array}{l}15 \sim 20 \mathrm{mg} \\
\text { 一般人の } 2 \sim 3 \text { 倍 }\end{array}$ & $50 \mathrm{mg}$ & & $15 \sim 20 \mathrm{mg}$ \\
\hline \multirow[t]{2}{*}{ 亜鉛 } & 0 件 & 1 件 & 0 件 & 0 件 \\
\hline & & $50 \mathrm{mg}$ & & \\
\hline \multirow[t]{2}{*}{ マグネシウム } & 0 件 & 2 件 & 0 件 & 0 件 \\
\hline & & $\begin{array}{l}300 \sim 350 \mathrm{mg} \\
500 \mathrm{mg} \sim\end{array}$ & & \\
\hline
\end{tabular}

\section{3）栄養素の必要量に関する記載内容}

栄養素の必要量に関する記載のみられた記事は合計 36 件であり，らち医師による記事が 27 件，栄養士 6 件，調
理師等 1 件, コーチ 2 件であった. 表 7 に, 栄養素別に 件数と内容をまとめたが, 1 件の記事中に複数の栄養素 について必要量が記載されていた場合は, 各栄養素ごと 
に 1 件と数えている. 記載内容（必要量）の各々につい ては件数を示していないが, 同一の内容が複数の記事に 載っていた場合もみられた。

たんぱく質についてはいずれの執筆者も必要量を記載 していたが，医師ではその他の各種ビタミン，ミネラル についても必要量を記載している例がみられた.

記載されていた必要量の出所が明記されているものは 注とんどみられなかったが，たんぱく質についてはLemon の推奖する值（持久運動時1. 2 $1.4 \mathrm{~g} / \mathrm{kg}^{2)}$, 筋力 トレーニング時1.7 1.8 g/ $\mathrm{kg}^{3)}$ ), Tarnopolsky らの推 奨量（筋力トレーニング時1.76 $\mathrm{kg}^{4)}$ ) 等に比べてやや大 きかったものの, Donath ら $\left(3.1 \sim 4.0 \mathrm{~kg}^{5)}\right)$ の推奨量 程ではなかった。一方, ビタミン A, Cについては日本 人の所要量 $\left.{ }^{6}\right)$ に比べて数倍〜 100 倍以上とかなり高い数 值があげられており，ビタミン Eについても目標摂取 量 ${ }^{6)}$ に比して数十倍以上といら高い值であった。また， 鉄, 亜鉛についても日本人の所要量, 推奨量 ${ }^{6)}$ に比して 数倍の数值であった.

運動時のビタミン，ミネラル必要量に関する研究は未 だ十分ではないが，動物実験およびヒトを対象とした実 験データをまとめてみると, 水溶性ビタミンやビタミン Eについては必要量が增大する可能性は考兄られるもの の, その他の脂溶性ビタミンについては必要量が増すと いう証拠は乏しいと考えられている7)。また, ビタミン や鉄の栄養状態が良くない場合には体力・競技能力の低
下がみられ，不足する栄養素の補給により能力が向上す るものの, それ以上過㮃に摂取しても効果は認められな いことも明らかにされている7). 亜鉛に関しては運動時 の必要量の検討に資するデータはまだ得られていない現 状である7).

こうした中で, 必要量として徒に高い数值が示され, その根拠も十分に説明されていないことには問題がある と思われた。特に，鉄など過剩摂取の障害が知られてい る栄養素については十分な配慮をもって数值を示す必要 があろう。

\section{4）栄養補助食品に関する記載}

栄養補助食品の記載について執筆者別に表 8 亿示し た。栄養補助食品についての記載がみられた記事は22件 （全件数の6.8\%）であり，筆者別では医師による記事 に多くみられた。紹介されていた栄養補助食品は, エネ ルギー，たんぱく質，ビタミン，鉄，カルシウム等を補 ら製品であったが，栄養補助食品に対寸る執筆者の考光 方によって取り上げ方に違いがみられた.

栄養士では，食事で十分に摂取できない時に栄養補助 食品をとることも一つの手段とする考劣であったが，医 師の中には栄養補助食品を積極的に薦める例も又られ， またコーチでは食事からのたんぱく質摂取よりもまずプ ロテインを薦める例もみられた。

栄養補助食品を安易に薦めることは，本来必要な食生 活の充実・改善が和万そかになる恐れがあるばかりでな

表 8 栄養補助食品に関する記載件数と内容

\begin{tabular}{|c|c|c|c|c|}
\hline 執筆者 & $\begin{array}{l}\text { 記載なし } \\
\text { 件数 }(\%) \\
\end{array}$ & $\begin{array}{l}\text { 記載あり } \\
\text { 件数 }(\%) \\
\end{array}$ & 補助食品名 & 説 \\
\hline 栄養士 & $137(45.7)$ & $1(4.5)$ & ビタミン剤 & 思らようにとれない時有効 \\
\hline 医師 & $90(30.0)$ & $14(63.6)$ & 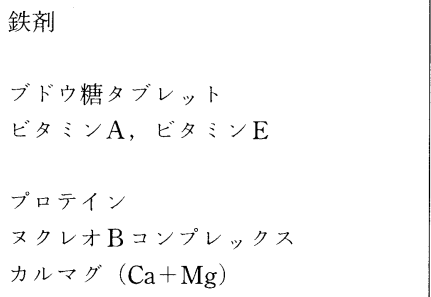 & 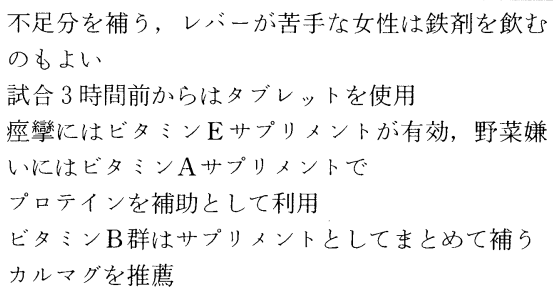 \\
\hline 大学教員 & $27(9.0)$ & $1(4.5)$ & エルネギー飲料，アミノ酸タブレット & 朝食から試合開始まで時間がある場合 \\
\hline 調理師等 & $24(8.0)$ & $2(9.1)$ & $\begin{array}{l}\text { エネルギー飲料 } \\
\text { プロテイン }\end{array}$ & $\begin{array}{l}\text { 補助食品で補らことも可能 } \\
\text { 食欲のない選手のために使用 }\end{array}$ \\
\hline コーチ & $20(6.7)$ & $3(13.6)$ & $\begin{array}{l}\text { アミノ酸 } \\
\text { デキストロース }\end{array}$ & $\begin{array}{l}\text { プロテインを利用し，あとはバランスを考えて好 } \\
\text { みのメニューを }\end{array}$ \\
\hline その他 & $2(0.7)$ & $1 \quad(4.5)$ & ビタミン郕 & \\
\hline 計 & $300(100)$ & $22(100)$ & & \\
\hline
\end{tabular}


く, 偏った栄養摂取や過剩摂取による障害を起こすこと も懸念される.

\section{5) まとめ}

以上の結果をまとめると, 今日のスポーツ雑誌には栄 養・食生活に関する記事が少なからず揭載されており, スポーッと栄湌との関わりについて関心が高まっている ことが明らかになったが，記事の内容については多少の 問題点もみられた.

栄養素とその働きについては, 概ね高等学校教科書に 取り上げられている程度の内容であったが, 栄責素の体 内に打ける働きについて代謝過程と関連つけた内容な ぞ, やや発展させたことがらもみられた，栄養素の必要 量に関して記載のみられた記事では, 数值の出典につい ては注とんど記されておらず, ビタミンや鉄の必要量は かなり高い数值があげられるなど, 読者に混乱を起こす 恐れもあると思われた。 また，例数は少なかったが，プ ロテインなどの栄養補助食品を積極的に薦める記述もみ られ，食生活を点検・改善するよりも手っ取り早くこれ らを利用することを助長するのではないかと懸念され る.

一因として，たんぱく質，ビタミン，ミネラルなどの 必要量に関するスポーツ栄養学の基礎的研究が未だ不十 分であることが考えられる. 早急な研究の推進が望まれ よう。また, 雑誌によって提供された情報を実際の食生 活に生かすためには, 食物や栄養に関する基本的な知識 を身につけていることが必要である.栄養素とその働き, 必要量, 食物に含まれる栄養素などの基礎的な知識は学 校教育において系統的, 実践的に学習されるが, スポー ツ活動を行ら中学生・高校生にはスポーツと関わらせな がら理解させる学習内容の工夫をすることも必要と思わ れる。

\section{要 約}

1992年から1996年までの 5 年間に, スポーツ雑誌 5 誌 に怙いては栄養・食生活に関連のある記事が少なからず 揭載され, 栄養士, 医師, 大学教員, コーチなどがその 執筆者であった.

記事の内容は多岐にわたっていたが，「食品紹介」,「栄 養バランス」,「コンディショニング」,「疲労回復」等に
関するものが多くみられた。

栄養素や食品の取り上げられ方については，(1)食品の みを取り上けているもの，(2)栄養素のみを取り上げてい るもの, (3)食品と栄養素を取り上げているものがあり, (2)では栄養素之その㗢さについて，さらに必要量につい ても記載されたものがみられた。 (3)では食品とそれに含 まれる栄養素，またその働きについて記載されたものは 多かったが，栄養素の必要量を記載したものは少なかっ た.

栄養素の働きに関する記述には, 高等学校の教科書で 説明されている内容以外のものも文られた。 これらの多 くは運動時の代謝にかかわる内容であり，医師により執 筆されたものに多い傾向がみられた，栄養素必要量に関 する記載については，たんぱく質，ビタミン，ミネラル についてみられたが，数値の出所が明記されているもの はほとんどみられず，特にビタミン，ミネラルでは日本 人の栄養所要量に較べて高值を示したものが多くみられ た.

栄養補助食品についての記載がみられた記事は多くな かったが，筆者別にみると医師によるものに多かった．

紹介されていた栄賈補助食品は，エネルギー，たんぱく 質, ビタミン, 鉄, カルンウム等を補ら製品であったが, 栄養補助食品に対する執筆者の考方方によって取り上げ 方に違いがみられた。

\section{参考文献}

1）金子佳代子, 三浦あゆ久, 太田和子, 高橋裕美, 伊藤 孝：横浜国立大学教育紀要，35，235（1995）

2) Lemon, P. W. R. : Int. J.Sports Nutr., 1, 127 (1991)

3) Lemon, P. W. R. : Nutr. Rev. 54, s169 (1996)

4) Tarnopolsky, M. A., MacDougall, J. D.,Chesley, A., Phillipse, S. and Schwarcz, H. P.: J. Appl. Physiol., 73, 1986 (1992)

5) 奥恒行, 橋本勲, 大畠襄, 郡英明, 岩永光一訳 : 勝つ ためのスポーツ栄養学一東ドイッの科学的栄養補給一, 南 江堂, 東京, p.92, 104, 113, 123，131，142（1990）

6）厚生省保健医療局健康増進栄養課：第五次改定日本人 の栄養所要量, 第一出版, 東京, p.115, 119, 123 (1994)

7) Hickson, J. F. and Wolinsky, I . : Nutrition in exercise and sport. CRC Press, Inc., Boca Ratoin, 233-278, 291308 (1989) 